\title{
THE FINANCIAL ANALYSIS OF THE HUNGARIAN AUTOMOTIVE INDUSTRY BASED ON PROFITABILITY AND CAPITAL STRUCTURE RATIOS
}

\section{Szucs, G.}

\begin{abstract}
The present study aims to investigate the economic processes taking place in the Hungarian automotive industry primarily by means of descriptive and multivariate statistical models. The purpose of the analysis is to present the performance of the sector via the ratios describing the operation. First the database and the applied methods - which are the factor and cluster analysis - will be described. Statement of the results begins with a descriptive statistical analysis of the financial ratios, where besides market share we get a whole picture of the operation of the determinative companies of the branch and the factors influencing the last six years. The capital structure ratios are examined in a separate chapter, where the changes of the last 10 years can be followed. The multivariate statistical models try to present a complex picture of the characteristics of the economic field and the underlying boundaries by means of the different ratios. On the basis of these findings, the study concludes that the automotive industry, which is named as a driving force of the economy, maintains its unbroken momentum predominantly due to the foreign-owned segment. Despite the given circumstances, the role of the liabilities is not of great importance.
\end{abstract}

Keywords: automotive industry; capital structure; principal component analysis, cluster analysis JEL classification: $\mathrm{G} 32$

\section{Introduction}

This study aims to give a whole picture about the performance of the Hungarian automotive industry and for this I apply index numbers, time series analysis and other multivariate statistical methods gained from the financial statements of the companies operating in the sector. Having in mind the importance of the sector in the national economy, I put special focus on the role of the foreign companies and the financing models applied by them.

\section{The Methods Applied for the Analysis}

I have downloaded the financial data of the companies operating in the automotive industry from the company database of Creditreform Kft. The raw data, financial statements and manpower data of all business organizations registered in Hungary can be found here. The sector of the automotive industry can be well defined by the NACE (The Integrated Branch Classification System of the Activities) classification, and therefore the 29 (production of road vehicle) and the 30 (production of other vehicles) codes were selected and used as a basis for the analysis. In case of the time series analysis, I worked 
with the whole database because in the previous years the currently inactive companies were also part of the branch. In case of the factor and the cluster analyses, I took into consideration only the current year's data, respectively only those companies can be found in the sample which status were active. Therefore I applied as a criteria the 100000 EUR revenue and positive shareholders' funds among the filter criteria. Then the capital structure, the profitability, the efficiency and the financial index numbers describing the company size were calculated that I thought to be the most relevant considering the operation. To track the latent structure underlying behind the ratios, I applied factor analysis, within this principal component analysis, which is based on the multicollinearity between the variables. The point of the analysis is preserving most of the information content carried by the original variables to create artificial variables that are new, independent from each other and of lower number compared to the original variables. Each component explains the variance of the variables in order of the eigenvalues, where the first factor contributes mostly while the others in a decreasing order to the total variance (Sajtos and Mitev, 2007). I tried to create factors that can be interpreted from an economic point of view as well, so I reached the model after several attempts that I considered to be the best. I performed the examination of the suitability of the data using the correlation and the anti-image matrix. The former reflects the correlation between the variables, without it they cannot be compressed into factors. The anti-image matrix is based upon the fact that the variance can be divided into explained and non-explained variance. The values in the main diagonal of the correlation matrix show how closely these variables are connected with all other variables. The main elements of the adequacy test is the Kaiser-MeyerOlkin (KMO) criteria, which also examine how suitable are the variables for the factor analysis. The higher its value, the lower the sum of squares of partial correlation coefficients between variable pairs (Brown and Székely, 2002). The next step of the examination is the clustering of the companies involved in the analysis based on the characteristics describing best their operation. Differences between the groups have to be the largest, and differences between the members of the group have to be as small as possible. For this task, cluster analysis is the appropriate method, where I will create the classification based on the previously defined factors. As in the factors, certain features are blurred so I am going to use some of the original variables during the analysis of the groups. The examined item number can be said to be large, so I chose K-means clustering. With this method, the cluster numbers should be determined in advance, so first I ran the hierarchical cluster analysis as well. Classification into the clusters depends on the distance between them and the cluster center. Thus the item falls into the cluster, which is closest to the center of its cluster. When all items have been classified, the center of each group is recalculated, and based on it the group composing will be repeated. The iteration will continue until we find a center after which there is no need for reclassification (Sajtos and Mitev, 2007). Referring to the examined period, there are 948 companies in the database which were the basis for the model of the time series analysis. In the further diminution the item number was reduced to 296 companies, where the examined index numbers were available in all cases, which were selected mainly according to the available literature and secondly on my previous experience. The minimum level of revenue was pulled by 100000 EUR; the companies performing under this were excluded from the analysis. In terms of capital structure, the rate of the liabilities, the non-current liabilities, and the current liabilities were among the examined variables. In terms of financing, I would 
mark the share of the non-current liabilities as crucial ratio as these are the resources assuming the creditability (Brealey and Myers, 1993).

\section{Results}

\subsection{The time series analysis of the ratios}

In terms of the net sales there are two periods; the boundary between them is the economic crisis in 2008. An upswing was observable until the mentioned date, when the examined ratio amounted to 14.1 billion EUR followed by a significant $28 \%$ decrease in 2009 . The branch reached the level of 2008 in nominal values in 2012 (in fact, it exceeded it with 800 million EUR), which was followed by an increase of $17.3 \%$ and resulted in the revenue of 17.5 billion EUR of the current year. The three flagship companies, Audi Hungaria, Mercedes-Benz Manufacturing and Magyar Suzuki own 54.3\% of the total market, which refers to the high concentration of the sector. This is supported also by the fact that $90 \%$ of the revenue is concentrated in 33 companies and 29 of them have a foreign owner. The whole sector is determined by foreign dominance as $92 \%$ of the revenue can be connected to these companies while their number is significantly lower than the domestically-owned firms. The current year's growth is largely due to the increase of Mercedes' 1.15 billion EUR growth in the examined result line. In addition, I have to mention the performance of the other dominant players as 8 out of 10 companies with the largest turnover have been able to achieve growth in the given ratio compared to 2012 .

\section{Figure 1 | Net sales and P/L before tax from 2008}

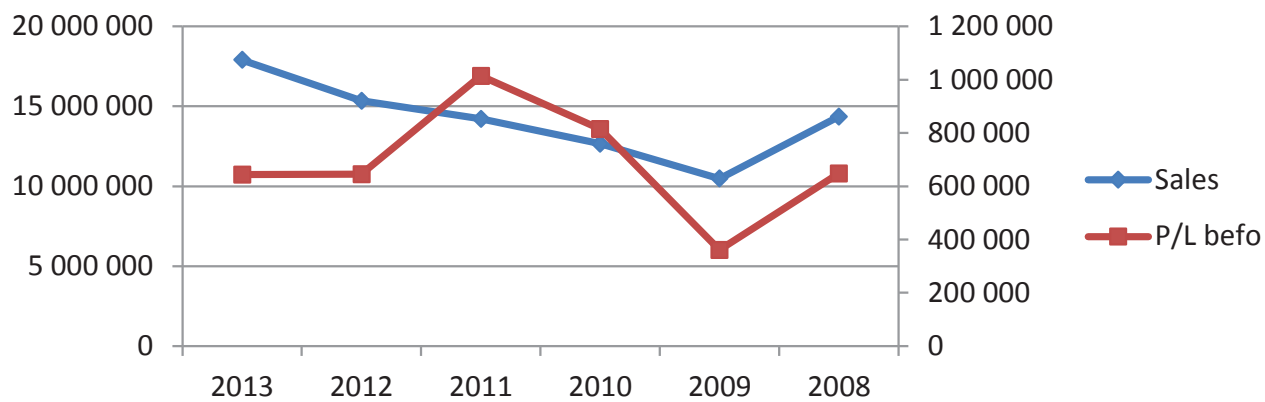

Source: Own elaboration based on Creditreform database

The export turnover is characterized by a similar concentration; here $90 \%$ of the sector's output is concentrated within 22 companies, only Audi has a 36\% share. The Hungarian automotive industry is characterized by a very high export orientation; the lowest value of the sectoral export ratio was $87 \%$ during the examined period and in the current year, it peaked with $90.8 \%$. Nine out of the 10 companies with the highest revenue had at least an index of $90 \%$ in 2013; the $99.7 \%$ export ratio of Mercedes and $97.8 \%$ export ratio of Audi rank amongst the highest. Seventy-seven out of the 107 companies with foreign owners had export sales, in case of the Hungarian companies, that are in the majority regarding their numbers; this can be said only in 55 cases. The operating profit 
index of the sector varies widely; here also the year of 2009 was the lowest point. The next two years meant the start-up period, the core business activity generated revenue of 1 billion EUR by 2011 which was the highest in the last 10 years. The decline of 380 million EUR experienced in the following year largely was due to the update of the clearing price system of the Audi Hungaria occurring in the other expenses category. The current year has been experiencing an increase of 106 million EUR while a negative financial result of 101 million EUR was suffered in the sector so the profit before tax line virtually didn't change. The growth of the revenue resulted in similar movements in the case of the expenses as well; the material costs were increased by 2.2 billion EUR, the costs of employees by 83 million EUR in a year. At the beginning of the examined period, the aggregate financial P/L was positive; from 2009 values close to zero were typical except for the year of 2013. In terms of P/L before tax, 486 companies were on the positive side, altogether realizing a profit of 778 million EUR. Forty-eight percent of this is concentrated in the two largest companies, Audi and Mercedes. 322 companies reached a negative result; they have suffered a loss of 197 million euro. Johnson Control itself made a loss of 45.6 million EUR of it. However, it is clear that the profit before tax is affected more by the income generated by the core business activity as a result of the financial operations including the cost of liabilities.

\section{Figure 2 | Result of financial operations}

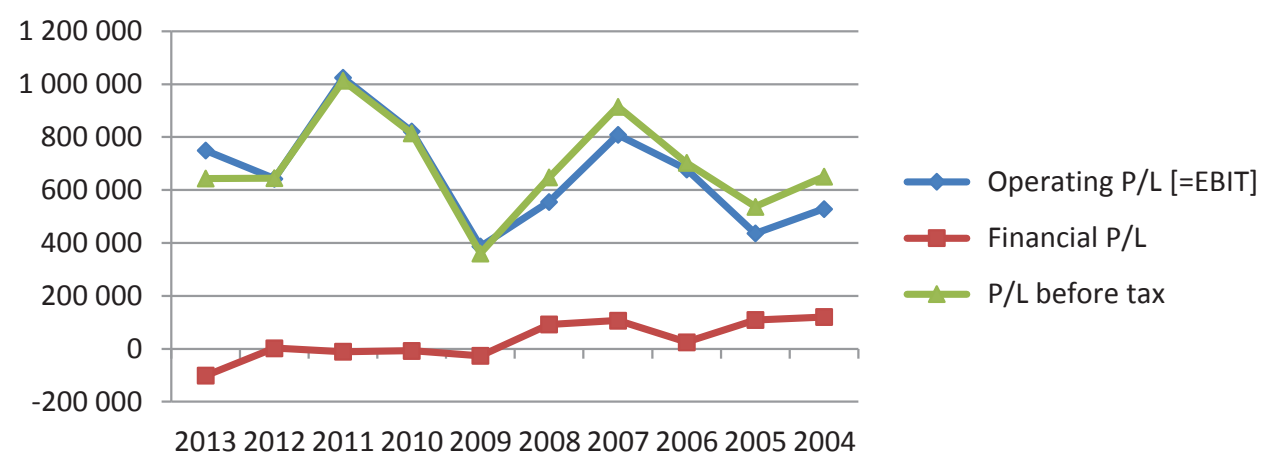

Source: Own elaboration based on Creditreform database

\subsection{Analysis of efficiency ratios}

Besides the profit margin, the return on equity and the assets were examined from the efficiency ratios' point of view. The ratios have been calculated with the correction of the extraordinary items. The three examined ratios changed similarly in the examined period. The year of 2009 had the lowest values similar to the earlier examined ratios; however, the efficiency experienced at the beginning of the period exceeds the ones experienced in the last few years. On one hand, this can be partly explained by the post-crisis recovery period; on the other hand by the turnover. The increase of the fixed assets and the number of employees suggest that the expansion of the sector is in progress currently as well and the return of the required expenses is expected in the forthcoming years. The increase of the revenue experienced in the current year wasn't followed by the increase of the 
profit after tax so the profit margin dropped from $4.2 \%$ to $3.6 \%$. The negative influencing impact of the result of the financial operations has to be mentioned here as well as the efficiency of the revenue generating capability of the core business activity didn't changed compared to the year of 2012. So it is easily recognizable that the current year's decrease of the ROE and the ROA isn't due to the decline of the profit generating capability but to the increase of the shareholders' funds occurred in their own line. Based on this, the year of 2011 is of outstanding importance when nominally all of the three involved balance sheets showed the highest value of the examined period and the efficiency ratios calculated from them showed a more positive picture as well. In 2012 there was a significant capital withdrawal in the branch when Audi Hungária decided about the payment of the dividend of 3 billion EUR; 2.67 billion EUR of this was charged to the retained earnings, which was $33.5 \%$ of the shareholders' funds of the entire sector. The assumed negative impact of the previously mentioned profit decline was set off by this drop so the ROA was more moderate (Figure 3.).

Figure 3 | Evolution of profitability ratios in the automotive industry

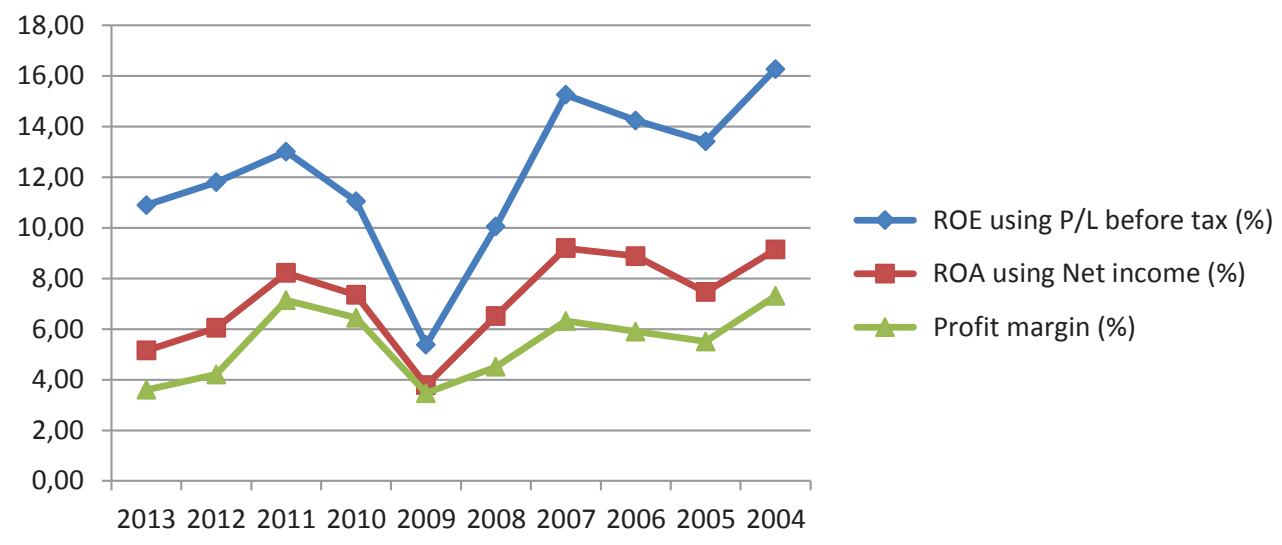

Source: Own elaboration based on Creditreform database

\subsection{Analysis of the capital structure ratios}

In 2013 the share of the sectorial liabilities was $46.3 \%$ compared to the total liabilities, so it was altogether five percentage points more than at the beginning of the period in 2004. Until 2009 a steady decline is observable in case of the ratios when the proportion of the liabilities dropped below 30\%. Then the ratio began to rise again and reached its current level. In terms of the expiry, the dominance of the current liabilities is typical. While the share of the non-current liabilities altered only between $6.8 \%$ and $11.1 \%$, the same in the case of the current liabilities is $20.8 \%$ and $34.3 \%$. However the proportion of the short-term loans in case of the current liabilities scarcely reaches $3 \%$ in the current year; the ratio was the highest in the year of 2009 (14.81\%). Regarding these facts, I draw a conclusion that the lending doesn't have a significant role in the Hungarian automotive industry. The market share of the companies that can be related to foreign owners exceeds $90 \%$; the ratios describing the profitability remained constantly in the positive range so the financing of the sector doesn't have any special risks. 
The share of creditors oscillated at higher levels within the short-term liabilities. Apart from the decline of 2006, the ratio was above $30 \%$ but a clear trend would be hard to determine. Generally we can say that companies with significant market power are in more favorable position in terms of creditors than their less dominant competitors. The applied long-term payment deadlines and the dependency of creditors support that funding method. Moreover the share of short-term liabilities has similar evaluation as the share of total liabilities since there is a minimal oscillation in case of the long-term liabilities.

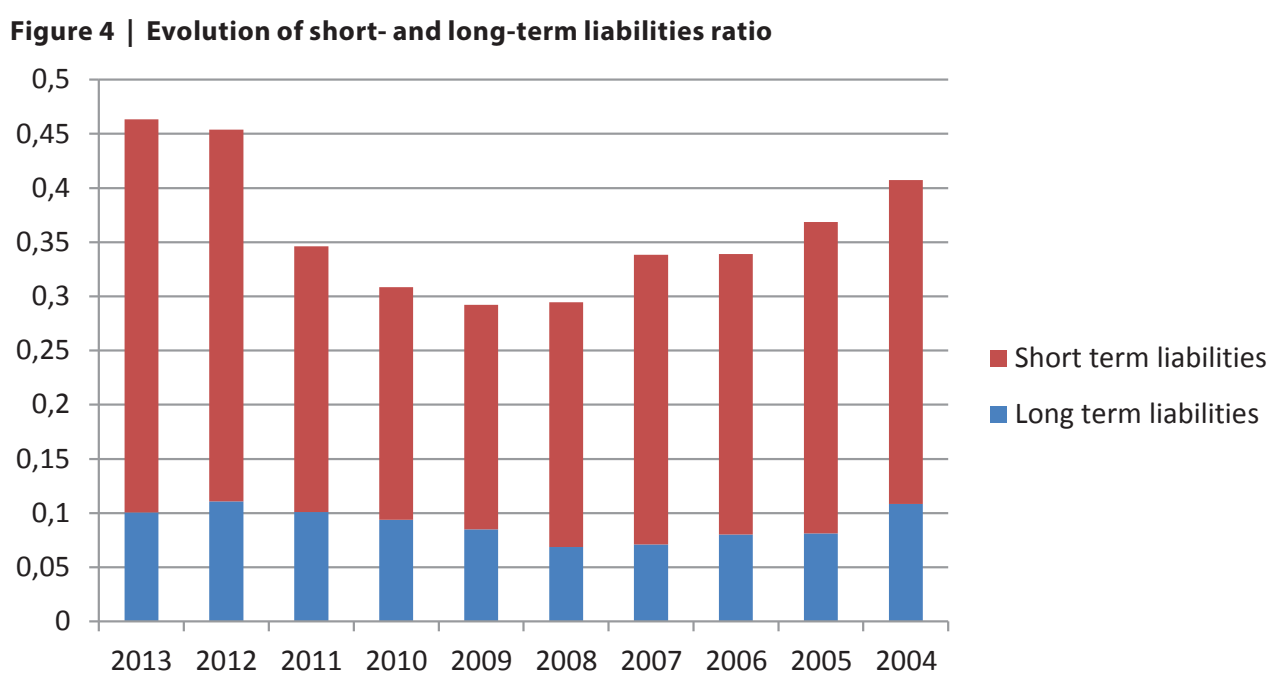

Source: Own elaboration based on Creditreform database

The role of over one year funds already considered marginal in the Hungarian automotive industry as the ratio barely exceeded $10 \%$ in the examined period. This is remarkable in light of the fact that fixed assets dominated over current assets from the year 2012 and the growth clearly occurred at the tangible assets line. As a result of this the aggregate value of tangible assets reached the $50 \%$.

\subsection{The result of the factor and cluster analysis}

I began the analysis with an examination of the adequacy of variables which is presented by the KMO test (Table 1.):

Table 1 | Result of KMO and Bartlett test

\begin{tabular}{|l|c|c|}
\hline \multicolumn{3}{|c|}{ KMO and Bartlett's Test } \\
\hline Kaiser-Meyer-Olkin Measure of Sampling Adequacy. & .662 \\
\hline \multirow{3}{*}{ Bartlett's Test of Sphericity } & Approx. Chi-Square & 1664.140 \\
\cline { 2 - 3 } & df & 36 \\
\cline { 2 - 3 } & Sig. & 0.000 \\
\hline
\end{tabular}

Source: Own elaboration based on SPSS 
The result exceeds 0.5 value, so the factor analysis can be performed by data set. Three such components formed from the original nine variables where the eigenvalues are greater than 1 (see Figure 5. in the supplement). The $76.9 \%$ of all information content is explained by the three components which exceeds the minimum $60 \%$ requirement (see Table 2. in the supplement).

Four variables got into the first principal component: profit margin, EBIT margin, return on equity (ROE) and return on assets (ROA) (Table 3.). Due to the characteristic of variables, I named this factor as profitability because all ratios refer to the income situation. As shown in the same direction, if a ratio has a high value then the rest will have high values as well. This factor contributes to the explanatory power of this model by $33.9 \%$.

Table 3 | State of factors after rotation

\begin{tabular}{|l|c|c|c|}
\hline \multicolumn{2}{|c|}{ Rotated Component Matrix } \\
\hline & 1 & 2 & 3 \\
\cline { 2 - 4 } & \multicolumn{2}{|c|}{ Component } \\
\hline Profit margin, \%, 2013 & .910 & -.208 \\
\hline EBIT margin, \%, 2013 & .881 & -.013 & -.228 \\
\hline ROA using P/L before tax, \%, 2013 & .862 & -.070 & .029 \\
\hline ROE using P/L before tax, \%, 2013 & .687 & -.075 & .027 \\
\hline LN turnover & -.052 & .928 & .051 \\
\hline Export revenue / Operating revenue, \%, 2013 & -.033 & .857 & -.034 \\
\hline Creditrors/Short-term liabilities, \%, 2013 & -.050 & .806 & .939 \\
\hline Short-term liabilities/Total assets, \%, 2013 & -.076 & -.038 & .932 \\
\hline $\begin{array}{l}\text { Total liabilities/Total Sharehol-ders' funds + } \\
\text { Liabilities, \% , 2013 }\end{array}$ & -.114 & .091 & \\
\hline $\begin{array}{l}\text { Extraction Method: Principal Component Analysis. } \\
\text { Rotation Method: Varimax with Kaiser Normalization. }\end{array}$ & \\
\hline a. Rotation converged in 4 iterations. & & & \\
\hline
\end{tabular}

Source: Own elaboration based on SPSS

Three ratios got into the second component: the natural logarithm of net revenue which should express the size of the company, ratios of export sales revenue and creditors. Regarding results obtained from the aggregated ratios of the examined sector, I named this factor as market power. Size of the company does not require any special explanation; the export orientation of this sector I think justifies the classification of the given ratio here. Creditors' ratio shows the ratio of so-called "forced lending" within the short-term liabilities. As a significant part of the sector made up by large foreign owned companies of considerable means, the high ratio of suppliers does not assume late payments or liquidity problems but rather the higher payment deadline, which is often 60 
days; however suppliers are obliged to accept these conditions. Because of this I consider the examined ratio as the index-number of market power in this case. The factor contributes to the explanatory power of this model by $24 \%$.

Two variables got into the third component: foreign capital and short-term liabilities ratios. Both ratios describe the capital structure, so I named this principal component as capital structure. Both ratios have a positive sign so they move together. The explanatory power of the whole factor is $21 \%$.

According to three factors, I found ideal the formation of three clusters which consist of 296 companies. Considering the sizes, two larger clusters and the one smaller one have been separated (Table 4.).

Table 4 | Number of elements in each cluster

\begin{tabular}{|l|c|c|}
\hline \multicolumn{3}{|c|}{ Number of Cases in each Cluster } \\
\hline \multirow{3}{*}{ Cluster } & 1 & 121.000 \\
\cline { 2 - 3 } & 2 & 38.000 \\
\cline { 2 - 3 } & 3 & 137.000 \\
\hline Valid & & 296,000 \\
\hline Missing & & 0,000 \\
\hline
\end{tabular}

Source: Own elaboration based on SPSS

There are 121 firms in the $1^{\text {st }}$ cluster, typically the flagships of the sector, which are characterized by high net revenue, export share and ratio of foreign owners. Since the latter ratio could take up 1 and 2 value depending on if the certain company has foreign interest or not, that is why based on the 1.66 average in this cluster $66 \%$ of the companies had a foreign owner. Compared to the sector average showing significant deviation, which is $33 \%$, the multitude mean was greatly exceeded by creditors and long-term liabilities ratios, which reinforces the strong market power of companies in the cluster (Table 5.). At the examination of the former, I made a conclusion that a majority of sectoral suppliers' outstanding debts focus on this segment. Total liabilities and short-term liabilities proportions are close to the sectoral average; at the same time, the profitability ratios even if slightly decreed it. Ratios around $5 \%$ are under the average of the total numbers, medians show almost the same value. The median value of tax effect is $6 \%$, which assumes significant undertaxation among companies dominating the Hungarian automotive industry. The proportion of longterm liabilities is rather low in the whole sector, typically this method of fundraising is not used, despite the fact that tangible assets ratio can be considered high for each cluster. Export ratio is the highest here and the median value is $83.6 \%$; it can be said that the vast majority of sectoral export is realized by these companies. From the maximum values of LN turnover ratio of the other two clusters, it comes to light that 30 companies with the largest net revenue belong to this group. Because of the high values performed at ratios defined as index-numbers of market power, I named this cluster as flagship companies. Values of certain ratios for each cluster are illustrated by the $5^{\text {th }}$ table in the supplement.

The item number of the $2^{\text {nd }}$ cluster is significantly less than the other two; however the examined group rises above the average in several aspects. The median value of 
foreign capital ratio is only $35.4 \%$, which is significantly lower than the mean value of all companies. Despite the fact that foreign and export shares are quite low (13 and 4.3\%), profitability ratios are far above the sectoral average. The average of profit before tax is $25.7 \%$, median value is $22.9 \%$ and the other profitability ratios show the same. Similarly to the total liabilities proportion, the share of the long- and short-term liabilities is the lowest in this cluster, which assumes the dominance of shareholders' equity in the financing structure. The average 6.43 LN turnover value covers an approximately 600000 EUR net revenue per year. Companies belonging here are characterized by low creditors' ratio and fairly good liquidity, because of the above-average profit rate I named these profitable companies.

Similar sized companies got into the $3^{\text {rd }}$ cluster such as in cluster two but based on the other ratios, we can experience significant differences compared to the sectoral average and the other two clusters. Although there is no significant separation according to capital structure ratios (50\% total liabilities ratio and $46 \%$ short-term liability ratio are very close to the sectoral average), on the basis of profitability the deviations are significant. Average value of EBIT and profit margin is under $2 \%$, liquidity is slightly above the desirable value. The proportion of foreign owners is modest here - only $10 \%$, and neither creditors nor long-term funds play an important role in financing (export share is the lowest here, only $1.42 \%)$. The tax effect is the highest here $(9.1 \%)$, which presents the tax scale as a function of profit/loss before tax. This does not necessarily mean that these companies are charged by a higher tax rate, because zero and negative result also have certain tax charge, so nominally lower tax payments may seem proportionally higher.

\section{Conclusion}

During the analysis of the automotive sector, which has outstanding significance to the national economy, I tried to explore its structure in the most comprehensive way and analyze ratios describing economy. Besides efficiency and profitability, I demonstrate the examination of capital structure in more detail, where I identified that the dominant forms of financing in the sector do not follow the procedures described in literature, maturity matching is not realized and company size is not determinant for the involvement of liabilities. I used the whole Hungarian database during the examination, while it was revealed that there is a very narrow group where the majority of the sectoral net revenue is realized and some companies are only nominally part of the sector, their economic role is considered marginal. During the descriptive statistical analysis mainly the structure of the sector has been discovered, we got to know the shares of certain market players and in what segment a significant part of net revenue is concentrated. The economy of the last six years is described by different ratios, where it turns out that the Hungarian vehicle industry has gone through continuous development, but almost exclusively the foreign owned companies were the driving force of this development; they have a major role in employment, but the under taxation and the capital withdrawals reveal their exact motivations. Looking into the future, the constant growth of the automotive sector can have a significant effect on domestic welfare and economic development but due to lack of labor positions with high additional value, this type of growth has limitations regarding the better life standards from many aspects. The R\&D expenses were significant only in the case of Audi; the other key players try to exploit the possibilities of the low labor costs and the additional tax reliefs. Therefore the comeback of the traditional domestic vehicle production remains a crucial challenge of the Hungarian economy. It can be realized only 
if the government will handle this segment with high priority and will support them with government orders. This would be the first step on the way back to the business cycle.

Among the multivariate statistical methods, I tried to make up different groups within the numbers with the help of factor and cluster analysis and finding connection between capital structure and profitability. Studies confirmed the results of the descriptive statistical analysis, that there are no models with different capital structure in the sector, the role of liabilities did not differ significantly based on profitability. Three groups stood out; one was formed by the already mentioned flagship companies. Besides this a similar sized cluster and one with fewer elements have been formed, which are well separated by size, export and suppliers' ratios from the first cluster. The profitability of the smallest group is much higher than the other two groups and the industry average. But their impact on industry performance was found to be less than significant since the turnover and the labor force was concentrated on the top companies of the first cluster. Foreign ownership is significant only at this cluster which includes companies with the largest net revenue, so it also forms a sharp dividing line between the groups. Companies in the high profitability group include lower rate of total liabilities; it is mostly concentrated on the other short-term liabilities. Suppliers' credit and long-term fund raising is practically the privilege of companies having high market power; however the role of the latter was not significant during the multivariate analysis.

The less determining role of the liabilities suggests that bank financing does not play a significant role in the sector, despite the existence of underlying assets the largest companies still heavily rely on equity financing which is supported by the profitability of the sector. The smaller companies - like in any other industry of Hungary - cannot count on bank loans; they can only apply for different grants and funding provided by the EU and governmental organizations.

\section{References}

Barna, I., Székely, M. (2002). Túlélőkészlet az SPSS-hez. Budapest: Typotex kiadó.

Brealey, R., Myers, S. (1993). Principles of Corporate Finance. McGraw-Hill: New York

Gyulai, L. (2011). Kis- és középvállalkozások üzletfinanszírozása, Saldo Pénzügyi Tanácsadó és Informatikai Zrt. Budapest

Kovács, E. (2006). Pénzügyi adatok statisztikai elemzése. BCE Pénzügyi és Számviteli Intézet. Budapest : Tanszék Kft.

Sajtos, L., Mlitev, A. (2007). SPSS kutatási és elemzési kézikönyv. Budapest: Alinea Kiadó.

Sztanó, I. (2006). A számvitel alapjai. Budapest: Perfekt Kiadó.

\section{Author}

\section{Gabor Szucs}

PhD Student

Szent Istvan University

Doctoral School of Management and Business Administration

Szent István University

H-2100 Gödöllő, Páter Károly utca 1.

g.szucsi@gmail.com 


\section{Appendix}

Table 2 | Variances of factors

\begin{tabular}{|c|c|c|c|c|c|c|c|c|c|}
\hline \multirow[t]{2}{*}{$\begin{array}{l}\text { Compo- } \\
\text { nent }\end{array}$} & \multicolumn{3}{|c|}{ Initial Eigenvalues } & \multicolumn{3}{|c|}{$\begin{array}{c}\text { Extraction Sums of Squared } \\
\text { Loadings }\end{array}$} & \multicolumn{3}{|c|}{$\begin{array}{l}\text { Rotation Sums of Squared } \\
\text { Loadings }\end{array}$} \\
\hline & Total & $\begin{array}{c}\% \text { of } \\
\text { Variance }\end{array}$ & $\begin{array}{l}\text { Cumula- } \\
\text { tive } \%\end{array}$ & Total & $\begin{array}{c}\% \text { of } \\
\text { Variance }\end{array}$ & $\begin{array}{l}\text { Cumula- } \\
\text { tive } \%\end{array}$ & Total & $\begin{array}{c}\% \text { of } \\
\text { Variance }\end{array}$ & $\begin{array}{l}\text { Cumula- } \\
\text { tive } \%\end{array}$ \\
\hline 1 & 3.055 & 33.940 & 33.940 & 3.055 & 33.940 & 33.940 & 2.844 & 31.596 & 31.596 \\
\hline 2 & 2.166 & 24.071 & 58.012 & 2.166 & 24.071 & 58.012 & 2.268 & 25.198 & 56.794 \\
\hline 3 & 1.905 & 21.164 & 79.176 & 1.905 & 21.164 & 79.176 & 2.014 & 22.382 & 79.176 \\
\hline 4 & .566 & 6.291 & 85.467 & & & & & & \\
\hline 5 & .531 & 5.895 & 91.362 & & & & & & \\
\hline 6 & .338 & 3.751 & 95.112 & & & & & & \\
\hline 7 & .210 & 2.335 & 97.447 & & & & & & \\
\hline 8 & .145 & 1.615 & 99.062 & & & & & & \\
\hline 9 & .084 & .938 & 100.000 & & & & & & \\
\hline
\end{tabular}

Source: Own elaboration based on SPSS

\section{Table 5 | Values of some ratios per clusters}

\begin{tabular}{|c|c|c|c|c|c|c|c|c|}
\hline \multicolumn{2}{|c|}{$\begin{array}{l}\text { Cluster Number } \\
\text { of Case }\end{array}$} & \multirow{2}{*}{$\begin{array}{c}\begin{array}{c}\text { Total liabilities/ } \\
\text { Total Shareholders } \\
\text { funds + Liabilities } \\
\%, \mathbf{2 0 1 3}\end{array} \\
121.00\end{array}$} & \multirow{2}{*}{$\begin{array}{c}\begin{array}{c}\text { LN } \\
\text { Turnover }\end{array} \\
121.00 \\
\end{array}$} & \multirow{2}{*}{$\begin{array}{c}\begin{array}{c}\text { Export revenue } \\
\text { / Operating } \\
\text { revenue } \\
\%, 2013\end{array} \\
121.00\end{array}$} & \multirow{2}{*}{$\begin{array}{c}\begin{array}{c}\text { Liquidity } \\
\text { ratio } \\
\mathbf{2 0 1 3}\end{array} \\
121.00 \\
\end{array}$} & \multirow{2}{*}{$\begin{array}{c}\begin{array}{c}\text { Creditrors/ } \\
\text { Short-term } \\
\text { liabilities } \\
\%, \mathbf{2 0 1 3}\end{array} \\
121.00\end{array}$} & \multirow{2}{*}{$\begin{array}{c}\begin{array}{c}\text { Foreign } \\
\text { owner }\end{array} \\
121.00\end{array}$} & \multirow{2}{*}{$\begin{array}{c}\text { ROA using } P / L \\
\text { before tax } \\
\%, 2013\end{array}$} \\
\hline 1 & $\mathrm{~N}$ & & & & & & & \\
\hline & Mean & 51.00 & 10.01 & 66.42 & 1.64 & 35.86 & 1.66 & 7.81 \\
\hline & Median & 51.91 & 9.66 & 83.58 & 0.85 & 32.02 & 2.00 & 7.25 \\
\hline & Minimum & 0.00 & 6.16 & 0.00 & 0.03 & 0.00 & 1.00 & -31.64 \\
\hline & Maximum & 96.83 & 15.60 & 99.96 & 20.07 & 92.46 & 2.00 & 32.90 \\
\hline \multirow[t]{5}{*}{2} & $\mathrm{~N}$ & 38.00 & 38.00 & 38.00 & 38.00 & 38.00 & 38.00 & 38.00 \\
\hline & Mean & 39.15 & 6.43 & 4.93 & 1.69 & 2.41 & 1.13 & 38.16 \\
\hline & Median & 35.46 & 6.16 & 0.00 & 0.92 & 0.00 & 1.00 & 32.89 \\
\hline & Minimum & 1.99 & 4.90 & 0.00 & 0.00 & 0.00 & 1.00 & 0.00 \\
\hline & Maximum & 97.70 & 10.11 & 98.20 & 27.38 & 30.98 & 2.00 & 86.82 \\
\hline \multirow[t]{5}{*}{3} & $\mathrm{~N}$ & 137.00 & 137.00 & 137.00 & 137.00 & 137.00 & 137.00 & 137.00 \\
\hline & Mean & 50.50 & 6.34 & 1.42 & 1.16 & 2.57 & 1.10 & 3.81 \\
\hline & Median & 49.99 & 6.13 & 0.00 & 0.70 & 0.00 & 1.00 & 2.92 \\
\hline & Minimum & 0.00 & 4.65 & 0.00 & 0.00 & 0.00 & 1.00 & -30.11 \\
\hline & Maximum & 99.51 & 11.04 & 55.98 & 16.33 & 43.29 & 2.00 & 27.81 \\
\hline \multirow[t]{5}{*}{ Total } & $\mathrm{N}$ & 296.00 & 296.00 & 296.00 & 296.00 & 296.00 & 296.00 & 296.00 \\
\hline & Mean & 49.25 & 7.85 & 28.44 & 1.42 & 16.16 & 1.33 & 9.85 \\
\hline & Median & 49.36 & 7.31 & 0.00 & 0.77 & 0.00 & 1.00 & 6.67 \\
\hline & Minimum & 0.00 & 4.65 & 0.00 & 0.00 & 0.00 & 1.00 & -31.64 \\
\hline & Maximum & 99.51 & 15.60 & 99.96 & 27.38 & 92.46 & 2.00 & 86.82 \\
\hline
\end{tabular}


Table 5 | Continuation

\begin{tabular}{|c|c|c|c|c|c|c|c|}
\hline \multicolumn{2}{|c|}{$\begin{array}{c}\text { Cluster Number of } \\
\text { Case }\end{array}$} & \multirow{2}{*}{$\begin{array}{c}\begin{array}{c}\text { EBIT margin } \\
\%, 2013\end{array} \\
121.00\end{array}$} & \multirow{2}{*}{$\begin{array}{c}\begin{array}{c}\text { Profit margin } \\
\%, 2013\end{array} \\
121.00\end{array}$} & \multirow{2}{*}{$\begin{array}{c}\begin{array}{c}\text { Tangible fixed } \\
\text { assets/Total assets } \\
\%, 2013\end{array} \\
121.00\end{array}$} & \multirow{2}{*}{$\begin{array}{c}\begin{array}{c}\text { Long-term } \\
\text { liabilities/ } \\
\text { Total }\end{array} \\
\begin{array}{c}\text { assets, \%, } \\
\mathbf{2 0 1 3}\end{array} \\
121.00\end{array}$} & \multirow{2}{*}{$\begin{array}{c}\begin{array}{c}\text { Tax effect } \\
\%, 2013\end{array} \\
121.00\end{array}$} & \multirow{2}{*}{\begin{tabular}{|c}
$\begin{array}{c}\text { Short-term } \\
\text { liabilities/Total } \\
\text { assets } \\
\%, 2013\end{array}$ \\
121.00
\end{tabular}} \\
\hline 1 & $\mathrm{~N}$ & & & & & & \\
\hline & Mean & 5.47 & 4.75 & 39.62 & 9.65 & 5.44 & 41.37 \\
\hline & Median & 4.68 & 3.85 & 38.48 & 4.32 & 6.03 & 38.37 \\
\hline & Minimum & -6.88 & -15.22 & 0.61 & 0.00 & -184.24 & 2.86 \\
\hline & Maximum & 25.67 & 25.25 & 91.84 & 58.79 & 98.60 & 96.53 \\
\hline \multirow[t]{5}{*}{2} & $\mathrm{~N}$ & 38.00 & 38.00 & 38.00 & 38.00 & 38.00 & 38.00 \\
\hline & Mean & 27.19 & 25.68 & 33.40 & 2.04 & 7.66 & 37.11 \\
\hline & Median & 23.18 & 22.91 & 33.13 & 0.00 & 9.38 & 33.52 \\
\hline & Minimum & 7.78 & 7.69 & 0.00 & 0.00 & 0.00 & 0.63 \\
\hline & Maximum & 84.92 & 81.06 & 86.40 & 15.95 & 19.81 & 91.40 \\
\hline \multirow[t]{5}{*}{3} & $\mathrm{~N}$ & 137.00 & 137.00 & 137.00 & 137.00 & 137.00 & 137.00 \\
\hline & Mean & 1.90 & 1.40 & 34.33 & 5.45 & 9.15 & 46.48 \\
\hline & Median & 2.69 & 2.06 & 30.81 & 0.00 & 9.15 & 40.74 \\
\hline & Minimum & -66.95 & -72.19 & 0.00 & 0.00 & -236.23 & 3.43 \\
\hline & Maximum & 17.14 & 14.29 & 92.53 & 70.73 & 394.87 & 99.51 \\
\hline \multirow[t]{5}{*}{ Total } & $\mathrm{N}$ & 296.00 & 296.00 & 296.00 & 296.00 & 296.00 & 296.00 \\
\hline & Mean & 6.60 & 5.89 & 36.37 & 6.73 & 7.44 & 43.19 \\
\hline & Median & 4.41 & 3.77 & 35.29 & 0.68 & 7.08 & 38.60 \\
\hline & Minimum & -66.95 & -72.19 & 0.00 & 0.00 & -236.23 & 0.63 \\
\hline & Maximum & 84.92 & 81.06 & 92.53 & 70.73 & 394.87 & 99.51 \\
\hline
\end{tabular}

Source: Own elaboration based on SPSS 
Figure 5 | Eigenvalues of components

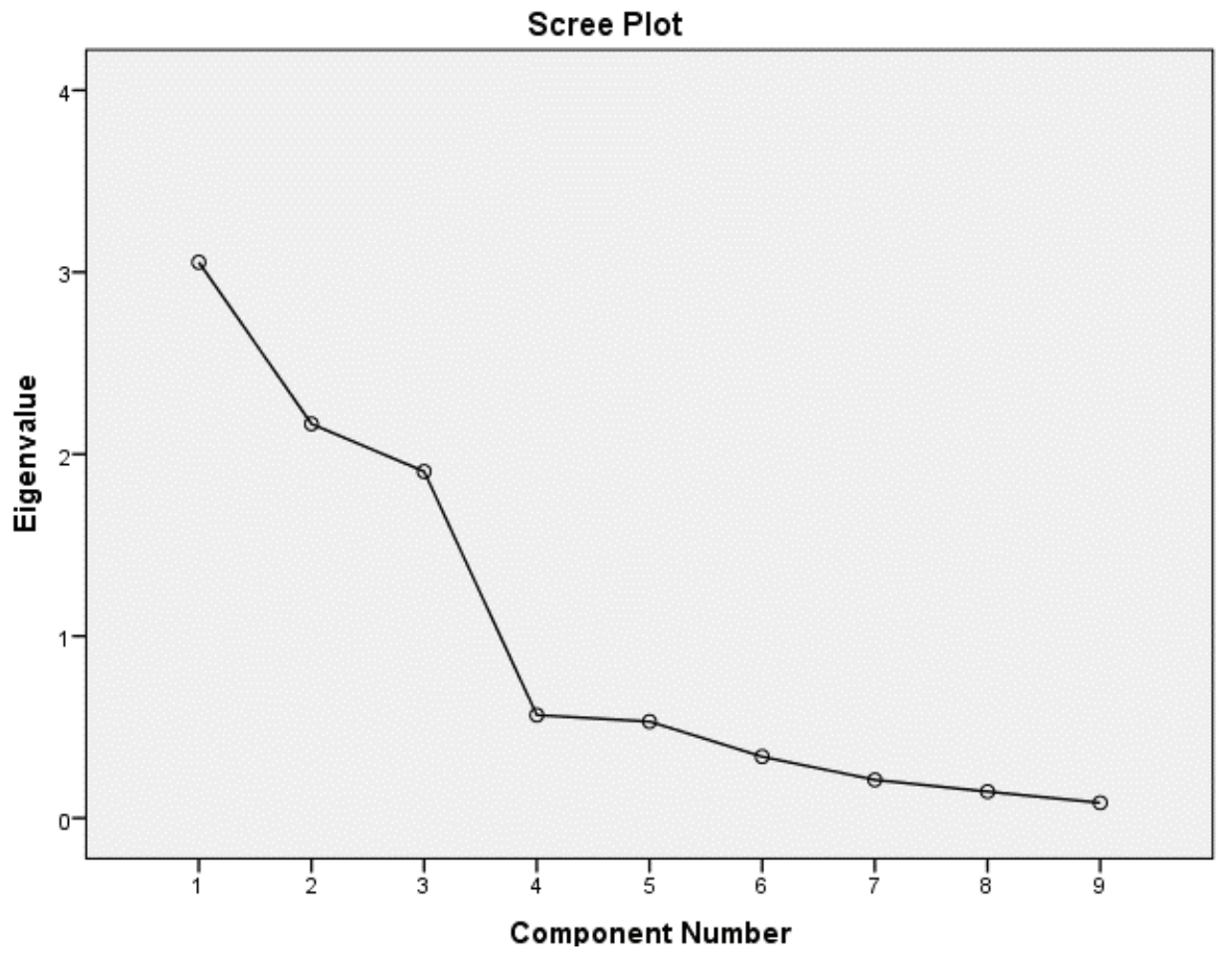

Source: Own elaboration based on SPSS 